\title{
HISTORIA HISTORIOGRAFII JAKO DZIEJE MYŚLENIA HISTORYCZNEGO
}

\section{ABSTRACT}

\section{HISTORY OF HISTORIOGRAPHY AS THE HISTORY OF HISTORICAL THINKING}

From time to time we ask ourselves about the status of our discipline. The answers to the questions regarding the methodology of history, the epistemology of history, the theory of history depend on the theoretical presuppositions of the researcher. The expectation that there is a single paradigm of research in the history of historiography requires the recognition and consent that there is one single mode of reflecting on history. In this article, I argue that the history of historiography can be understood as history of historical thinking in all its contexts.

\section{KEYWORDS:}


Co jakiś czas zadajemy sobie pytanie o status dyscypliny. W naszym kręgu, a więc w kręgu metarefleksji nad historią odpowiedzi na pytanie o metodologię historii, epistemologię historii, czy teorię historii uzależnione są od tego jaką opcję teoretyczną reprezentuje odpowiadający, nie zaś od tego jak to niby dzisiaj jest. Odpowiedź na pytanie o status historii historiografii wśród nauk historycznych zależy nie tyle od tego jaki ustabilizował się konsensus we wspólnocie badawczej w rzeczonej kwestii, ile jakie stanowisko zajmuje badacz odpowiadający na pytanie wyrażające wspomniany problem. Oczekiwanie, że obowiązuje jakiś jeden paradygmat uprawiania historii historiografii, chcąc nie chcąc - wymagałoby uznania, że panuje standard rozumienia historii i zgoda co do tego, że dominuje jeden sposób uprawiania refleksji nad historią. Jest tak dlatego, że środowisko badaczy, którzy uznają się za kompetentnych w sprawie jest rozległe i różnorodne, pytanie o to czym jest dzisiaj historia historiografii umożliwia niemal nieograniczone jego rozumienie. A jest to rezultat wieloznaczności terminu historia, jak i różnych możliwych znaczeń terminu historiografia.

Nie jest więc dla mnie problemem, że nie ma jednej, zgodnej odpowiedzi na pytanie czym jest dzisiaj historia historiografii. Co więcej i mało tego, nie istnieje standardowy sposób wykładu rodzajów historii historiografii.

Na pytanie o to czym jest dzisiejsza historia historiografii odpowiadam całkiem subiektywnie: jak w świetle mojego rozumienia kontekstu współistnienia historii z innymi naukami o człowieku jawi się zadanie historii historiografii. Zaczynam od najogólniejszego rozróżnienia jakie udało mi się dostrzec w moim rozumieniu historii historiografii. Pierwsze, traktuje historię historiografii jako dyscyplinę historyczną, aspekt nauki o przeszłości, której jedynie fragmentem jest praktyka utrwalania na piśmie dziejów, określonego wycinka przeszłości. Historia historiografii to dzieje pisarstwa historycznego, nie mniej poważna dyscyplina historyczna niż dzieje kultury, literatury, praktyk religijnych, dzieje oświaty, czy historia polityki. Jeśli można zajmować się przeszłością literatury, to można zajmować się dziejami literatury historycznej, eposu, poematu historycznego, powieści historycznej, traktatu historycznego, czy naukowego dzieła historycznego.

Drugie, traktuje historię historiografii nie jako dzieje elitarnego odnoszenia się do przeszłości, ile jako losy wspólnotowej praktyki poznawczej. Ujmuje ją jako aspekt poznawczego stosunku do świata. Historia historiografii, to dzieje sposobów zapamiętywania i zglębiania świata minionego. Historia historiografii drugiego rodzaju, to dzieje utrwalania godnych zapamiętania lub/i prawdziwych wymiarów ludzkiego świata minionego. To dzieje myślenia historycznego. 
Aby te dystynkcje uczynić bardziej zrozumiałymi, trzeba je kontekstowo uporządkować. A zatem zacznijmy od podstawowych rozstrzygnięć, jakie stają za moim utożsamieniem: historia historiografii, to dzieje myślenia historycznego.

Warunkiem powstania historycznego myślenia jest ufundowanie się w kulturze dualizującego sposobu mówienia i myślenia. Przekonującym sposobem opisu tego przełomowego cywilizacyjnie zjawiska jest Josefa Mitterera, Tamta strona filozofii. Wraz z ukonstytuowaniem się rzeczywistości myślowej i pozamyślowej (językowej i pozajęzykowej w tym podmiotu i przedmiotu myśli) powstaje myślenie/mowa o przeszłości. Jedną z możliwości sugestywnego opisania tego procesu jest koncepcja Borisa Uspienskiego wyłożona w pracy Ego Loquens ${ }^{2}$, która poznanie wiąże z aktem komunikowania, traktując pierwotny akt mowy skutecznej w dialogu jako embrionalną interpretację, a więc pierwotny akt poznawczy. Nie upieram się oczywiście, że mój sposób rozumienia procesu komunikowania, czy poznania - przedstawiany tu w kontekście tych dwóch koncepcji (Mitterera i Uspienskiego) jest najlepszy, czy jedyny. Nie w tym rzecz, abyśmy zgodzili się, że zarówno instrumentarium pojęciowe, jak i filozoficzny sens tak widzianego procesu jest trafny. Rozumowanie poniższe ilustruje jedynie sytuację, gdzie można/trzeba podejmować decyzje aby sposób myślenia o historii historiografii był ugruntowany. Jakiego rodzaju pokłady interpretacji kultury mogą być uruchomione wtedy, gdy tak, czy inaczej pojmuje się jakiś aspekt nauki o człowieku.

Rosyjski semiotyk kultury buduje w polu kulturologicznym odpowiedź na pytanie, jak powstanie w procesie komunikowania/poznania wspólnotowe wyobrażenie świata rzeczywistego (realnego/obiektywnego). Twierdzi, że funduje się i manifestuje się ono

1 Mitterer J., Tamta strona filozofii. Przeciwko dualistycznej zasadzie poznania, przeł. M. Łukasiewicz, Warszawa 1999, została w głównym zrębie napisana w latach 1973-1978. Das Jenseits der Philosophie. Wider das dualistische Erkenntnisprinzip. Wien: Passagen Verlag, 1992. Zasadnicza część 100 tez o Tamtej stronie filozofii pochodzi zapewne z lat siedemdziesiątych. Aneks zaś prawdopodobnie z początku dziewięćdziesiątych. Całość ukazała się prawdopodobnie w 1993 roku (?). W roku 2004 ukazało się tłumaczenie kolejnej książki austriackiego filozofa: Ucieczka z dowolności, przeł. A. Zeidler-Janiszewska, Oficyna Naukowa, Warszawa 2004; omawiam tę pracę w tekście: Wrzosek W., $W$ poszukiwaniu fundamentów myślenia (historycznego). Ostatni referat: Tamta strona filozofii, Josefa Mitterera, w: Florilegium Historicum Amicorum Munera. Profesorowi Krzysztofowi Maciejowi Kowalskiemu w sześćdziesiątą piąta rocznicę urodzin przyjaciele, koledzy, uczniowie, red. T. Maćkowski, Grajewo 2016, s. 81-88. Zob. także recenzje: Abriszewski K., „Ruch Filozoficzny” 1999, 3-4, s. 403-408; Bińczyk, E., Josefa Mitterera ucieczka od esencjalizmu, Er(r)go. Teoria-Literatura-Klutura, 2005, nr 10, s. 187-194. W tym ostatnim tekście omawiana jest zasadniczo Ucieczka od dowolności, ale nie tylko.

2 Успенский Б.А., Ego Loquens. Язык и комуникационное пространство, Москва 2007, wyd II 2012; W związku z kwestią czasu historycznego (czasu deiktycznego) prezentuje ją Karolina Polasik-Wrzosek w tekście Polasik-Wrzosek K., Wrzosek W., W poszukiwaniu czasu historycznego. Od metamorfozy magicznej do metafory genezy, w: Mitte viros qui considerent terram... Między nauka a sztuką - wokót problemów wspótczesnej historiografii, Lublin 2017, Wyd. UMCS). Korzystam z tam poczynionych ustaleń, ale i aplikuję je do mojego tu rozumowania. 
w akcie komunikowania. Akt mowy, jest - o ile skuteczny komunikacyjnie - źródłem utwierdzania się dialogujących co do wymiaru świata obiektywnego. Ów pomyślany i zasygnalizowany językowo świat, wyznacza warunki dla kolejnych aktów komunikacyjnych, które kontynuowane wzbogacają wspólnotowe doświadczanie świata, rozwijają semantykę języka i zasób stanów rzeczy postrzeganych jako istniejące.

Poniższy schemat ilustruje $e^{3}$ - równoczesne warunki jakie muszą być spełnione, aby komunikowanie zaszło oraz jak powstaje i rozwijać się może pojmowanie rzeczywistości obiektywnej przez daną wspólnotę komunikacyjną. W tym konstytuuje się pojęcie przeszłości w ramach chronotopu dialogu.

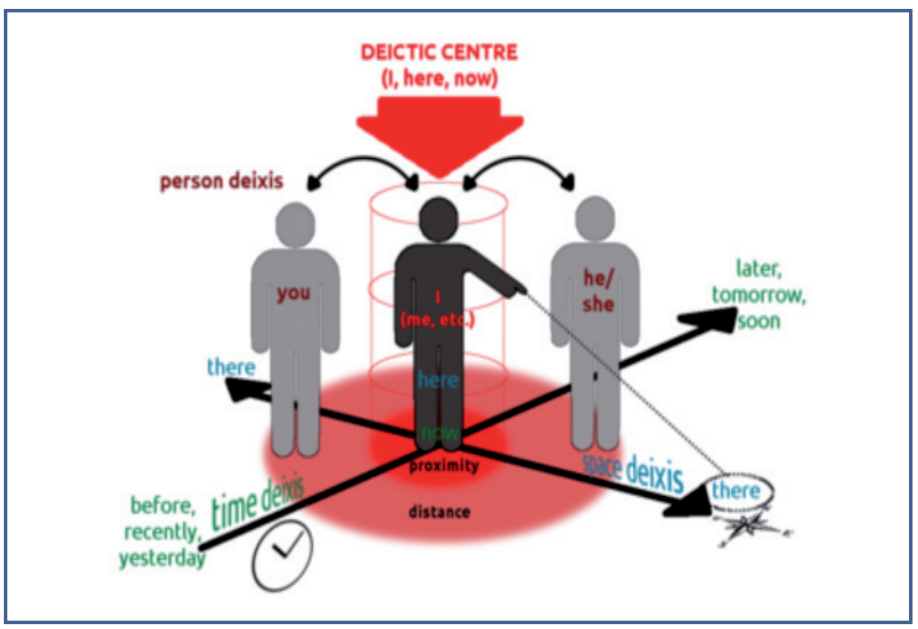

Komunikowanie bierzemy jako świadectwo myślenia za nim stojącego. Bez tych założeń trudno wyobrazić sobie jak byłoby możliwe. A więc Komunikant A, deiktyczne centrum „ja” (I, here, now - na schemacie ) jest nie do pomyślenia bez „ty” (you, there, now (?)).

„I tak, argumentuje rosyjski semiotyk, zaimek osobowy ja oznacza tego, kto wypowiada „ja” (kto określa siebie jako ja w akcie mowy). Zaimek osobowy ty odnosi się do tego, kto może wskazywać na siebie jako na ja w procesie komunikacji (w sytuacji dialogu). Zaimki osobowe on, ona, ono, (he, she) jeśli mowa jest o osobie, odnoszą się do tego, kto może oznaczać siebie jako ja poza aktem komunikowania (poza sytuacją dialogu). Możemy więc uznać, że ty związane jest $\mathrm{z} j a$, równocześnie on (ona, ono) związane jest z ty (... ) Pomijając niuanse, które można znaleźć w analizach Uspienskiego

3 Schemat ten nie pochodzi od Uspienskiego, użyty został pomocniczo przez K. Polasik-Wrzosek, w jej wykładzie czasu deiktycznego konceptu będącego efektem Uspienskiego interpretacji roli wyrażeń deiktycznych w postulowaniu tzw. obiektywnej rzeczywistości. Tamże. 
konkluzja jego brzmi następująco: (... ) zaimek osobowy ja jawi się jako pierwotny (wyjściowy) względem innych zaimków osobowych: W rzeczy samej, związek z ja (odniesienie do ja) milcząco obecne jest w zaimkach ty i on (ona, ono), ponieważ, zarówno ty, jak i on (ona, ono) - jeśli ten ostatni zaimek oznacza osobę - występują jako potencjalni mówiący: ci, którzy mogą wskazywać na siebie jako na ja. Można powiedzieć, że ja tworzy semantyczne centrum zaimków osobowych”4.

Uspienski zajmując się konstytuowaniem się tzw. rzeczywistości obiektywnej jako wspólnej (wspólnotowej) dla uczestników procesu komunikowania się - marginesie jedynie - postrzega problem wspólnotowego chronotopu. Powstaje on - można powiedzieć - jako efekt niezamierzony aktu komunikowania się/porozumiewania ${ }^{5}$. Tu przyglądając się schematowi widzimy doniosłość konstytucji wspólnego chronotopu dla - co najmniej - ja i ty, ale i fundowanie się poczucia przeszłości i przyszłości jako miejsca ulokowania się zarówno dla potencjalnego uczestnika dialogu ja/ty, tj. dla on, ona, ono (osobowe i nieosobowe). Dzięki potencjalnemu (pomyślanemu, milczące$\mathrm{mu}$ ) udziałowi on (ona ono) w fundowaniu świata deiktycznego, świata z centrum $\mathrm{w}$ ja oraz bezpośrednio i pośrednio związanego z nim w procesie komunikowania świata fundowanego dzięki deiktycznym zaimkom osobowym (poza ja) powstaje domniemanie przyszłości i założenie o przeszłości. Potencjalność udziału innych poza ja/ty udziałowców w komunikowaniu się bierze się z niezbywalnego założenia, że ty może wystąpić w roli ja oraz via/dzięki ty on (ona, ono) podobnie mogą być dla ty, ty, wtedy, gdy ty podejmie rolę ja w komunikowaniu. Dopuszczenie świadomości okazjonalności zaimków osobowych, w tym w szczególności biorących się od w istocie z okazjonalnego ja nieosobowego zaimka ono zespala je w układ podmiot/ przedmiot.

Tak można przedstawić proces wyłaniania się dualizującego sposobu myślenia ${ }^{6}$ i mówienia, jeśli tylko - przypomnimy, że za aktem komunikowania stają określone

4 Успенский Б.А., Ego Loquens..., s. 22; Uspienski cytuje w przypisie 59 Martina Bubera: "Jeśli powiedziano ty, to jednocześnie z tym powiedziano ja z pary ja-ty. Jeśli powiedziano ono, to wraz z tym powiedziano ja z pary ja-ono." Wenn Du gesprochen wird, ist das Ich des Wortpaars Ich-Du mitgesprochen. Wen Es gesprochen wird, ist das Ich des Wortpaars Ich-Es mitgesprochen” Buber M., Ich und Du, Köln 1966, s. 9. "Jeśli powiedziano ty, to jednocześnie z tym powiedziano ja $z$ pary ja-ty. Jeśli powiedziano ono, to wraz z tym powiedziano ja z pary ja-ono." Pomijamy tu niuanse związane $\mathrm{z}$ wieloznacznością zaimków osobowych jako wyrażeń deiktycznych, możliwością rozumienia deiktyczności, które wchodzą w grę wtedy gdy a akcie mowy ujawniają się one np. jako okazjonalne, czy jako wskazujące, etc.

5 Kwestię tę podejmuje Karolina Polasik-Wrzosek w artykule $W$ poszukiwaniu... Analizy tam poczynione są w oparciu o I wydanie Ego Loquens, tu zaś cytowane fragmenty z Uspienskiego pochodzą już z wydania drugiego z 2012 roku, w tłum. K. P. Polasik-Wrzosek.

6 Kwestię, czy za aktem mowy stoją akceptowane założenia wspólne nadawcy i adresata, czy tylko są one wcielane w życie odruchowo, tj. przyjęte wraz z poręcznościowo przyswojonym sposobem praktykowania otoczenia pozastawiam na boku wyrażając intuicję, że do zainicjowania aktu mowy wystarczą milcząco respektowane wspólne doświadczenie świata. Np. Успенский Б.A., Ego Loquens..., wyd. II, s. 9. O kulturologiczne wyzyskanie kategorii poręczności M. Heideggera postarała się Anna Pałubicka, Pałubicka A., Myślenie w perspektywie poręczności a pojęciowa konstrukcja świata, Epigram, Bydgoszcz 2006. 
przesądzenia myślowe co do sytuacji wokół „centrum deiktycznego”, tj. co do tego czym jest ja i wszystko elementarne wokół niego. W szczególnej roli pozostaje ono osobowe i bezosobowe jako przedmiot aktu mowy, który może być później nazwany obiektem aktu poznania, a już równocześnie z aktem mowy potencjalnością podziału na przeszłość, teraźniejszość, przyszłość. Refleksja nad minionymi stanami rzeczy, prowadzona przez ja i zastępujące $j a$, inne podmioty, to kontynuacja aktów mowy na temat minionych on (ona, ono). To zauważmy namysł, świadomość istnienia bytów poza aktualnym chronotopem ja/ty. Zasadne jest sądzić, że tak jak co do doświadczania teraźniejszości, tak i przeszłości, w miarę komunikowania się, następuje porozumienie. Formuje się - wynegocjowany - obraz rzeczywistości minionej, element współtworzący poczucie bezpieczeństwa ontologicznego wspólnoty`.

Kluczową dla mnie konkluzją jest taka oto opinia Uspienskiego: Moje relacje ze współrozmówcą przenoszą się (ekstrapolują) na jego relacje z innym rozmówcą (w stosunku do którego on staje się ja, a tamten okazuje się dla niego ty)” „Dlatego możemy mówić o istnieniu tego, czego teraz nie ma: przypuszczamy - kontynuuje rosyjski badacz - , że między mną i egipskim faraonem, który, jak przypuszczam, istniał tysiąclecia temu, następują pokolenia, które mogły przekazywać sobie wzajemnie doświadczenia. Podobnie, możemy mówić o istnieniu świata, w którym jeszcze nie było ludzi, przypuszczając przy tym, że jeśliby oni w tych światach byli, mogliby obserwować to, o czym my mówimy. Odpowiednio, w miarę naszego oddalania się od bezpośredniego doświadczania, problem istnienia staje się coraz bardziej konwencjonalny"

Przekonują więc mnie argumenty, że elementarne akty mowy, tj takie, które zakładają komunikowanie rozumiejące między nadawcą a odbiorcą ${ }^{10}$, zakłada już to wspólny zarys świata, o którym jest mowa, ale i szkic wspólnego rozumienia tego co było i czego można spodziewać się, że będzie także wtedy gdy zmieni się ja.

Dygresja powyższa jakkolwiek fragmentarycznie relacjonuje sferę założeń, jaką skłonny jestem przyjmować wtedy, gdy pyta ktoś o sprawy pozostające daleką ich

7 Wykładnie kategorii tej znajdziemy w pracy: Bezpieczeństwo ontologiczne. Zbiór rozpraw, red. A.Dobosz, A. P. Kowalski, Epigram, Bydgoszcz 2007. W rozprawach tych najpopularniejsze jest ujęcie Anthony` ego Giddensa (Giddens A., Nowoczesność i tożsamość „ja” i spoteczeństwo w epoce późnej nowoczesności, przeł. A. Szulżycka, PWN, Warszawa 2001), tak eksplikują je autorzy wstępu: „Można powiedzieć, że składają się na nie m.in. specyficzne odczucie czy doświadczenie tożsamości naszego „ja”, pewne przekonanie o charakterze filozoficznym, mówiące o realności świata oraz pewne przekonania potoczne, zgodnie z którymi świat jest zbiorem uporządkowanych obiektów połaczonych statymi zależnościami, w szczególności związkiem przyczynowo-skutkowym. Wszystko to ma zapewnić człowiekowi (relatywnie) komfortowe funkcjonowanie $w$ świecie"

8 Tamże, s. 36

9 Tamże.

10 Komunikowanie rozumiejące w tym tu ujęciu to być może takie, które nie ustaje po pierwszych sekwencjach mowy obu stron i nie zakłóca działań praktycznych prowadzonych w trybie poręczności. Nie staje na przekór praktykowaniu świata w trybie odruchowym. 
konsekwencją, to mam nadzieję pokazuje, gdzie mogą kryć się przesądzenia, o tym, że tak, a nie inaczej kwalifikuję świat kreślony przez historiografię. W konsekwencji myślę o historii historiografii.

A więc, dzięki dualizującemu sposobowi myślenia i mówienia przywykliśmy dzielić nasze poznanie - w tym historyczne -, na podmiot poznający i przedmiot poznania. W przypadku, poznania historycznego, które jak ufamy wyłania się już w pierwszym akcie mowy zakładającym obecność w nim potencjalnego on (ona, ono - zwłaszcza bezosobowego), uzyskujemy podział na ja (my) teraźniejszość/współczesność i on (oni) przeszłość. Tym samym, myślenie o przeszłości jest kulturowym warunkiem oralnej refleksji historycznej i dalej pisanej, a także nie od dzisiaj, audiowizualnej.

Niezależnie od zasadności podobnych analiz, poszukujących genezy historycznego myślenia w początkach procesu porozumiewania się językowego, $\mathrm{w}$ domniemaniu równoczesności obu tych procesów, refleksja wokół historiografii, w tym z gatunku dziejów historiografii może uwzględniać daleko sięgające poszukiwania kulturowych uwarunkowań tożsamości i zmienności historii lub pozostać dla konkretnych potrzeb kulturowych dalece zredukowanym namysłem nad przeszłością praktyk odnoszenia się do przeszłości.

A więc, ze względu na powiązanie mniej lub bardziej systematycznej refleksji nad przeszłością z historią historiografii, a więc myślenia historycznego z tradycją pisarstwa historycznego, historia historiografii może być wyposażona w plytki, bądź głęboki kontekst historyczno-kulturowy. W zależności od niego jawi się jako powiedzmy tradycyjny dyskurs faktograficzny, tj. uporządkowany chronologicznie opis biografizujący historiografię, będący historią historyków i ich twórczości, genetyczny zestaw idei i problematyki historycznej wedle epok pisarstwa historycznego, narodowo/ państwowo,wyznaniowo/językowo selekcjonowany materiał historiograficzny ujęty w stosowne monografie, zespół danych historiograficznych jako materiał pomocniczy do wykładu epok, czy faz dziejów, wedle biegu dziejów powszechnych lub regionalnych.

Historia historiografii może być rozumiana jako dzieje myślenia historycznego, we wszelkich możliwych kontekstach analiz myślenia historycznego, bo historia historiografii, to dzieje myślenia historycznego, niezależnie od instrumentarium, czy mediów umożliwiających myśleniu temu artykułowanie się i uobecnianie w kulturze ${ }^{11}$.

11 Teza „Historia historiografii to dzieje myślenia historycznego” znajduje swą realizację w moich książkach: Historia - Kultura - Metafora. Powstanie nieklasycznej historiografii, Wrocław 1995, wyd. II, Wrocław 2010 oraz O myśleniu Historycznym, Bydgoszcz 2009. 